\title{
SISTEM INFORMASI INVENTORY DATA BARANG PADA UD. MUTIARA MEUBEL BERBASIS WEB
}

\author{
*Guslan ${ }^{1)}$, Rodianto ${ }^{2)}$ \\ ${ }^{1), 2)}$ Informatika Universitas Teknologi Sumbawa \\ guslanaja5@gmail.com ${ }^{\text {I) }}$,rodianto@uts.ac.id ${ }^{2}$
}

\begin{abstract}
Abstraksi
Sistem Informasi Inventory Data Barang Pada UD. Mutiara Meubel, yang bertujuan untuk memudahkan dalam proses meng-input data barang dan proses teransaksi yang tidak lagi dilakukan secara manual yang dapat berlangsung dengan lebih cepat dan efisien serta dapat mengurangi tingkat kesalahan yang mungkin terjadi. Metode penelitian yang dilakukan adalah kualitatif dengan melakukan pengumpulan data,observasi pengamatan secara langsung wawancara, dan dokumentasi.Data yang digunakan meliputi data stok barang data proses transaksi. Analisis data, serta metode perancangan sistem yang digunakan dibuat melalui tahapan-tahapan definisi alur kerja sistem yang berjalan, Data Flow Diagram, perancangan database, serta desain Input-Output sistem. Dari pengamatan serta penelitian yang dilakukan dapat diketahui. UD. Mutiara Meubel memerlukan pengolahan data berupa sitem Informasi Inventory yang memudahkan dalam proses meng-input Barang dan mencari barang yang telah di-input, sehingga diharapkan akan menhasilkan Sistem Informasi Inventory Data Barang yang lebih baik dari sistem manual.
\end{abstract}

Kata Kunci : Sistem Informasi Inventory Data Barang Pada UD. Mutira Meubel

\section{Abstraction}

Inventory Data Information System at UD. Mutiara Meubel, which aims to facilitate the process of inputting goods data and transaction processes that are no longer done manually which can take place more quickly and efficiently and can reduce the level of errors that may occur. The research method that is carried out is qualitative by conducting data collection, direct observation of interviews, and documentation.The data used includes data on item inventory transaction process data. Data analysis, and system design methods used are made through the stages of the system workflow definitions that are running, Data Flow Diagrams, database design, and design of the Input-Output system. From observations and research carried out can be known. UD. Mutiara Furniture requires data processing in the form of an Inventory Information system that facilitates the process of inputting Goods and looking for items that have been inputted, so that it is expected to produce a Goods Data Inventory Information System that is better than a manual system.

Keywords: Inventory Data Information System at UD. Mutira Meubel

\section{Pendahuluan}

1.1 Latar Belakang

Dengan semakin ketatnya persaingan bisnis di dalam dunia usaha, kecepatan dan ketetapan dalam bertindak dalam suatu hal merupakan yang utama. Pengelolaan yang baik dalam bidang bisnis sangat diperlukan untuk memperlancar kinerja. Ada beberapa sistem pada suatu bidang bisnis, salah satunya adalah sistem informasi inventory barang, yang berfungsi untuk mengetahui jumlah barang pada gudang. Sistem informasi inventory barang merupakan suatu sistem yang dibuat untuk mengetahui jumlah barang atau barang apa saja yang terdapat di gudang. Disamping itu, pengunaan sistem persedian barang yang baik diharapkan akan mengurangi resiko kesalahan dan hilangnya ataupun pencurian terhadap persedian barang.

UD. Mutiara Meubel merupakan salah satu toko meubel terbesar di wilayah Kecamatan Plampang yang bergerak dibidang penjulan meubel, Elektronik dan 
alat-alat rumah tangga, dimana pengolahan inventorydata masih dilakukan secara manual. Proses Transaksi masih dilakukan dengan cara mencatat dalam pembukuan sebagai bukti untuk pelaporan hasil transaksi kepada pemilik. Selain itu proses pencarian dan pengecekan barang masi dilakukan dengan cara yang sama, dengan mengecek secara fisik sehingga pemeriksaan dan pelaporan hasil transaksi barang masuk dan barang keluar dirasa belum efektif dan efisien karena akan memakan waktu yang lumayan lama untuk proses pembuatan laporan dan pada proses pencarian barang.

Untuk mendukung kinerja dan kwalitas agar memiliki nilai tambah dalam hal kenyaman palanggan atau konsumen dalam proses mengetahui jenis dan stok barang yang ingin dibeli dan khususnya karyawan dan pemilik toko. Sesuai dengan kebutuhan toko Penulis akan membuat "Sistem Informasi Inventory Data Barang pada UD. Mutiara Meubel Berbasis Web" dimana nantinya bertujuan untuk membantu pegawai atau pemilik dalam menginput data barang. Selain itu, pengguna dapat membuat hasil transaksi, barang masuk dan barang keluar secara langsung dalam bentuk laporan mingguan ataupun bulanan. Dengan adanya bentuk laporan tersebut, perkembangan dan tingkat keuntungan pada toko dari tahun ke tahun dapat diketahui oleh pemilik toko tanpa harus melakukan pengecekan ulang pada setiap dukumen dan nota penjualan dan pembelian pada setiap proses transaksi.

\subsection{Tujuan Penelitian}

Adapun tujuan dari penelitian ini yaitu merancang Sistem inventory data barang dengan menggunakan $P H P$ dan basis data $M y S Q L$ yang dapat digunakan oleh karyawan atau pemilik toko yang akan memudahkan pelayanan, pengolahan data dan transaksi yang telah terjadi di UD. Mutiara Meubel

\section{Tinjauan Pustaka 2.1 Inventory}

Menurut Nugrahayati (2015:15) Inventory adalah memenuhi semua permintaan pelangan dengan persediaan barang yang semenimal mungkin. namu kita tidak boleh melihat keuntungan yang kita peroleh hanya dengan memperhatikan segi dari inventory bagian gudang saja karena inventory mempengaruh dalam semua apartemen yang ada dalam suatu perusahan.

Menurut Yunarto (2005:2) Inventory adalah item atau material yang dipakai oleh suatu organisasi atau perusahan untuk menjalankan bisnisnya. Jika perusahan tersebut memperoduksi suatu barang atau jasa maka material tersebut digunakan untuk mendukung dan menyediakan kebutuhan produksi. Inventory bagi perusahan adalah untuk mengantisipasi kebutuhan pelangan. Begitu juga dalam industry manufacturing. Inventory digunakan untuk aktifitas perusahan yang mana untuk memenuhi pelanggan yang kadang kala tidak dapat diprediksi sehingga kita harus menjaga stok inventory dalam kegiatan produksi. Hal yang tidak dapat diprediksi bukan saja terjadi atas pelanggan yang menginginkan barang dari perusahan kita. Inventory juga berperan sebagai buffer dalam hal supply dan demand. Sementara itu, inventory juga berperan sebagai buffer dalam hal supply memenuhi customerdemand (permintaan dan kebutuhan pelanggan), menyediakan komponen-komponen yang dibutuhkan untuk produksi.

Dari bebarapa pendapat ahli diatas dapat ditarik kesimpulan bahwa sistem inventory merupakan suatu proses penginputan data barang yang berisi tentang data stok barang yang dapat membantu proses produktivitas pada toko atau suatu perusahaan.

\subsection{Sistem Informasi}

Menurut Sutabri (2012:16) sistem adalah sekelompok unsur atau komponen yang erat hubungannnya satu dengan yang lain yang berfungsi bersama sama untuk mencapai tujuan tertentu. Terdapat dua kelompok pendekatan di dalam mendefinisikan sistem yaitu sistem yang menekankan pada prosedurnya dan sistem yang menekankan pada komponen atau elemennya.

Model umum sebuah sistem adalah input, proses, dan output. Hal ini merupakan konsep sebuah sistem yang sangat sederhana sebab sebuah sistem dapat mempunyai beberapa masukan dan keluaran. Selain itu, 
sebuah sistem mempunyai karakteristik atau sifat - sifat tertentu yang mencirikan sebagai suatu sistem. Adapun karakteristik suatu sistem adalah komponen sistem, batasan sistem, lingkungan luar sistem, penghubung sistem, masukan sistem, keluaran sistem, pengolahan sistem, sasaran sistem.

Menurut Putra (2011:42) Informasi merupakan data yang telah diolah menjadi bentuk yang lebih berguna dan lebih berarti bagi penggunanya yang relevan, akurat dan kelengkapan informasi.

Sistem merupakan suatu prosedurprosedur yang saling berhubungan berkumpul bersama-sama untuk melakukan suatu kegiatan atau untuk menyelesaikan suatu tujuan tertentu.

\subsection{CodeIgniter}

Menurut Hakim (2010:42) CodeIgniter adalah sebuah framework PHP yang dapat membantu mempercepat developer dalam pengembangan aplikasi web berbasis $P H P$ dibanding jika menulis semua kode program dari awal.

Menurut Daqiqil dan Ibnu (2011:16)

CodeIgniter pertama kali dibuat oleh Rick Ellis, CEO Ellislab, Inc. (http://ellislab.com), sebuah perusahaan yang memproduksi CMS (Content Management System) yang cukup handal, yaitu Expression En gine (http://www.expressionengine.com). Saat ini, CodeIgniter dikembangkan oleh Expression Engine Development Team.

Menurut pendapat dua ahli diatas maka dapat disimpukan bahwa codeIgniter merupakan sebuah web application network yang bersifat open source yang dapat digunakan untuk membangun aplikasi $p h p$ yang dinamis.

\subsection{Xampp}

Menurut Nugroho (2013:01) XAMPP adalah paket program web lengkap yang dapat Anda pakai untuk belajar pemrograman web, khususnya $P H P$ dan $M y S Q L$.

Menurut Buana (2014:03) XAMPP adalah perangkat lunak opensource yang diunggah secara geratis dan bisa dijalankan disemua operasi seperti windows, linux, solaris, dan mac.
Berdasarkan pendapat diatas dapat disimpulkan bahwa Xampp merupakan salah satu jenis program yang dapat kita pergunakan untuk mempelajari pemrograman Web secara gartis yang bisa berjalan di windows, linux, solaris, dan mac.

\subsection{Metode Waterfall}

Menurut Pressman (2015:42) Metode yang digunakan untuk pengembangan perangkat lunak penulis menggunakan metode waterfall model klasik yang bersifat sistematis, berurutan dalam membangun software. Nama model ini sebenarnya adalah "Linear Sequential Model". Model ini sering disebut juga dengan "classic life cycle" atau metode waterfall. Model ini termasuk ke dalam model generic pada rekayasa perangkat lunak dan pertama kali diperkenalkan oleh Winston Royce sekitar tahun 1970 sehingga sering dianggap kuno, tetapi merupakan model yang paling banyak dipakai dalam Software Engineering (SE). Model ini melakukan pendekatan secara sistematis dan berurutan. Disebut dengan waterfall karena tahap demi tahap yang dilalui harus menunggu selesainya tahap sebelumnya dan berjalan berurutan.

Menurut Rosa dan shalahuddin (2013:28) Model SDLC air terjun (waterfall) sering juga disebut model sekuensial linier (sequential linear) atau alur hidup klasik (class life cycle).Model air terjun menyediakan pendekatan alur hidup perangkat lunak secara sekuensial atau terurut di mulai dari analisis, desain, pengkodean, pengujian dan tahap pendukung (support).

Penulis menggunakan metode waterfall ini karna pembuatan aplikasi tersebut dirasa sesuai dengan keperluan dan tahapan-tahapan yang ada pada metode waterfall.

\section{METODOLOGI PENELITIAN}

\subsection{Metode Pengumpulan Data}

Beberapa tahap untuk mendapatkan data dan informasi penulis menggunakan beberapa metode, yaitu diantaranya metode pengamatan wawancara, observasi dan dukumentasi. Adapun metode pengumpulan data yang digunakan penulis adalah sebagai berikut : 
a. Observasi

Observasi dilakukan dengan melakukan pengamatan langsung pada UD. Mutiara Meubel untuk mengidentifikasi masalah dan analisis kebutuhan rancang bangun sistem yang akan dilakukan.

b. Wawancara

Wawancara merupakan percakapan antar dua pihak dengan maksud tertentu. Dalam penelitian ini, wawancara dilakukan kepada pemilik toko UD. Mutiara Meubel bapak $H$. Bahtiar H.M yang bertujuan untuk memperoleh izin dalam melakukan penelitan mengenai bahan dan data yang dibutuhkan dalam penelitian.

c. Dokumentasi

Dokumentasi digunakan untuk melengkapi kebutuhan dan kesempurnaan data penelitian yang dilakukan di UD. Mutiara Meubel Data diambil berdasarkan sumber data arsip ataupun dokumentasi data pada toko dari hasil proses transaksi, stok barang dan pembukuan dari laporan dan hasil transaksi yang berlangsung di UD. Mutiara Meubel.

\subsection{Metode Pengembangan Perangkat Lunak}

Adapun Metode pengembangan perangkat lunak yang digunakan dalam membangun Sistem Informasi Inventory data barang pada UD. Mutiara Meubel berbasis Web yaitu menggunakan metode Waterfall.

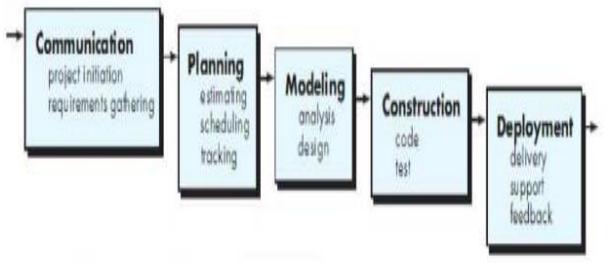

Gambar 3.1.Tahapan-Tahapan MetodeWaterfall

a. Communication (Project Initiation \& Requirements Gathering)

merupakan tahap yang dilakukan oleh peneliti dalam mengembangkan sistem. Dalam analisa ini harus mendapatkan beberapa hal yang dianggap menunjang penelitian yang dilakukan, kebutuhan pengguna atau user, perangkat keras, dan perangkat lunak. Dengan menggunakan analisa kebutuhan sistem maka dapat diketahui kebutuhan apa saja yang diperlukan dalam membangun sistem informasi inventory barang.

Adapun kebutuhan dari pengguna. admin atau pemilik dapat melakukan proses penyimpanan data inventory barang, admin atau pemilik dapat mengedit dan menghapus data inventory barang, dan dapat melakukan pencarian data barang, pergguna atau user hanya dapat melihat gambar barang, jumlah stok barang dan harga barang.

b. Planning (Estimating, Scheduling, Tracking)

Tahap berikut adalah tahapan perencanaan yang menjelaskan tentang estimasi tugas-tugas yang akan dilakukan, resiko-resiko yang dapat terjadi, penjadwalan kerja yang akan dilaksankan, dan tracking proses pengerjaan sistem

c. Modeling (Analysis \& Design)

Pada tahap ini dilakukan penterjemahan analisa kebutuhan ke dalam bentuk rancangan sebelum penulisan program, yang bertujuan untuk mengatasi permasalahan yang ada. Tahapan - tahapan yang dilakukan dalam desain sistem adalah sebagai berikut :

1. Perancangan sistem, alat yang digunakan adalah Data Flow Diagram (DFD).

2. Perancangan Basis Data, alat yang digunakan adalah Entity Relationship Diagram (ERD) dan spesifikasi tabel yang digunakan untuk Sistem Informasi Inventory data barang.

3. Perancangan layar interface, yaitu perancangan layar untuk input data dan rancangan layar untuk output.

d. Construction (Code \& Test)

Tahap mentransformasikan desain kedalam baris-baris program yaitu dengan menggunakan bahasa pemrograman Hypertext Preprocessor(PHP) dan MySQL sebagai database.

e. Deployment (Delivery, Support, Feedback)

Pada tahap ini dilakukan uji coba pada web Sistem Informasi Inventory 
barang di UD. Mutiara Meubel yang telah dibuat. Proses uji coba ini diperlukan untuk memastikan web tersebut sudah berjalan sesuai dengan karakteristik yang diharapkan, Dan dilakukanya pemeliharaan sistem agar dapat terus digunakan.

\subsection{Alat dan bahan penelitian}

Adapun alat dan bahan yang digunkan dalam penelitian ini adalah sebagai berikut :

a. Kebutuhan minimum perangkat lunak untuk pembuatan sistem informasi pengelolaan data inventory barang adalah sebagai berikut :

Tabel 3.1.Spesifikasi Perangkat Lunak

\begin{tabular}{|c|l|c|}
\hline No & \multicolumn{1}{|c|}{$\begin{array}{c}\text { Perangkat } \\
\text { Lunak }\end{array}$} & Keterangan \\
\hline 1 & $\begin{array}{l}\text { Sistemoperasi } \\
\text { untuk } \\
\text { menjalankan } \\
\text { program }\end{array}$ & $\begin{array}{c}\text { Windows } 7,64 \\
\text { bit }\end{array}$ \\
\hline 2 & $\begin{array}{l}\text { Development } \\
\text { tool }\end{array}$ & Sublime Text 3 \\
\hline 3 & Database & $\begin{array}{c}\text { MySql versi } \\
10.1 .21\end{array}$ \\
\hline 4 & Web Server & $\begin{array}{c}\text { Xampp versi } \\
5.6 .30\end{array}$ \\
\hline
\end{tabular}

b. Kebutuhan perangkat lunak

Kebutuhan perangkat keras untuk pembuatan sistem informasi pengelolaan data inventory barang yaitu :

Tabel 3.2Spesifikasi Perangkat Keras

\begin{tabular}{|c|l|c|}
\hline No & \multicolumn{1}{|c|}{$\begin{array}{c}\text { Perangkat } \\
\text { Keras }\end{array}$} & Keterangan \\
\hline 1 & Processor & $\begin{array}{c}\text { Intel }{ }^{\circledR} \\
\text { Celeron }\end{array}$ \\
\hline 2 & RAM & $2 \mathrm{~GB}$ \\
\hline 3 & Harddisk dan & $500 \mathrm{~GB}$ \\
\hline 4 & $\begin{array}{l}\text { Mouse Standar } \\
\text { Keyboard }\end{array}$ \\
\hline
\end{tabular}

c. Kebutuhan pengguna

Adapun kebutuhan penguna dalam sistem informasi inventory data barang ini adalah sebagai berikut :
Tabel 3.3 Kebutuhan pengguna

\begin{tabular}{|c|l|l|}
\hline No & Pengguna & \multicolumn{1}{|c|}{ Hak Akses } \\
\hline 1 & $\begin{array}{l}\text { Admin atau } \\
\text { Pemilik }\end{array}$ & $\begin{array}{l}\text { Dapat } \\
\text { menginput, } \\
\text { mengedit, } \\
\text { menghapus dan } \\
\text { membuat laporan } \\
\text { dari hasil } \\
\text { teransaksi }\end{array}$ \\
\hline 2 & Petugas & $\begin{array}{l}\text { Dapat } \\
\text { menginput, } \\
\text { mengedit, dan } \\
\text { menghapus data }\end{array}$ \\
\hline 3 & $\begin{array}{l}\text { User } \\
\text { ataupenggun } \\
\text { a }\end{array}$ & $\begin{array}{l}\text { Hanya dapat } \\
\text { melihat gambar } \\
\text { barang jumlah } \\
\text { stok dan harga } \\
\text { barang }\end{array}$ \\
\hline
\end{tabular}

\section{HASIL PENELITIAN}

\subsection{Alur Kerja Sistem Berjalan}

Berdasarkan hasil wawancara, dokumentasi dan wawancara yang telah dilakukan pada UD. Mutiara Meubel diketahui sistem yang sedang berjalan pada saat ini masih menggunakan cara yang manual seperti transaksi pembelian, penjualan, pengecekan persediaan barang dan pelaporan hasil dari setiap transaksi masih dilakukan secara manual seperti terlihat pada gambar di bawah ini :

\subsubsection{Proses Input Data Pembelian Barang.}

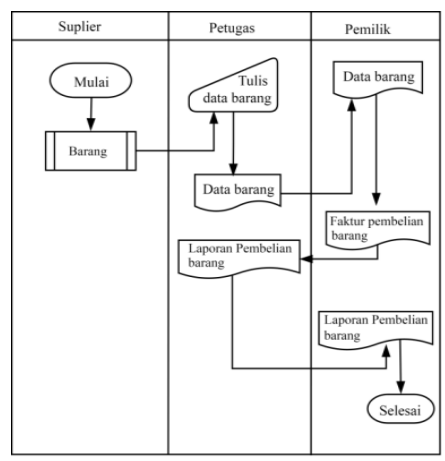




\section{Gambar 4.1 Flow mapInput Data Pembelian Barang}

Berdasarkan tampilan Gambar 4.1 dalam transaksi pembelian di UD.Mutiara Meubel yaitu sebagai berikut:

1. Dimulai dengan suplier melakukan pengantaran barang di UD.Mutiara Meubel

2. Kemudian diterima oleh petugas tokoh dan melakuklan penulisan data barang yang akan diterima

3. Selanjutnya dibuat dalam bentuk data barang

4. Dan melakukan pemberitahuan kepada pemilik tokoh berupa data barang

5. Pemilik tokoh membuat faktur pembelian barang

6. Dibuatlah dalam bentuk laporan barang oleh petugas

7. Kemudian diserahkan kembali kepada pemilik tokoh dalam bentuk laporan pembelian barang

\subsubsection{Proses Input Data Penjualan Barang}

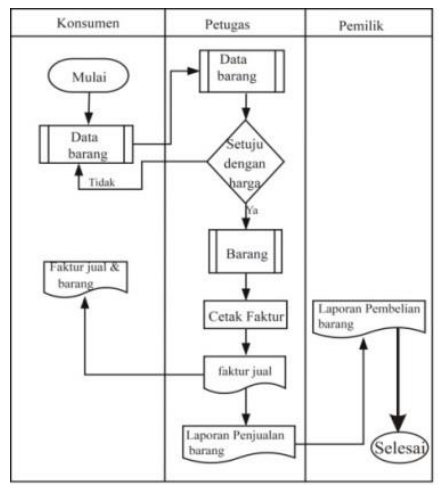

\section{Gambar 4.2 Flow map Input Data penjualan Barang}

Berdasarkan tampilan Gambar 4.2 dalam transaksi penjualan di UD.Mutiara Meubel yaitu sebagai berikut:

1. Dimulai dengan komsumen melihat barang

2. Kemudian konsumen tertarik dengan barang

3. Selanjutnya petugas memberi tahukan harga barang yang di inginkan

4. Jika konsumen setuju dengan harga barang

5. Dan jika konsumen tidak setuju dengan harga makaakan kembali ke data barang untuk melihat barang yang diinginkan
6. Maka petugas akan meniapkan barang dan membuat faktur pembelian

7. Kemudian barang dan faktur penjualan diberikan kepada kunsumen

8. Berlanjut dari faktur penjualan kemudian petugas membuat laporan penjualan kepada pemilik

\subsection{Alur Kerja Sistem Diusulkan \\ 4.2.1 Proses Input Data Pembelian}

\section{Barang yang Diusulkan}

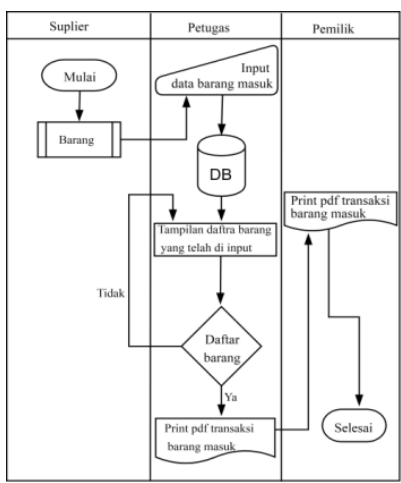

Gambar 4.3 Flow mapInput Data Pembelian Barang yang Diusulkan

1. Dimulai dengan suplier melakukan pengataran barang

2. Kemudian petugas menginput data barang untuk di masukan kedalam penyimpanan databases

3. Lalu menampilkan daftar barang yang telah di input

4. Selenjutnya ada proses pemilihan daftar barang apakah ingin melakukan print pdf transaksi barang masuk atau tidak maka proses akan kembali ke daftar barang

5. Kemudian setelah petugas melakukan print pdf maka laporan dari hasil transaksi pembelian yang diprint dalam bentuk pdf diserahkan kepada pemilik toko 


\subsubsection{Proses Input Data Penjualan yang Diusulkan}

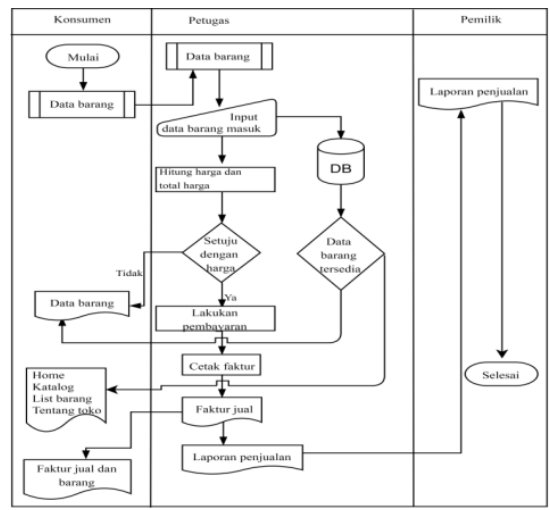

Gambar 4.4 Flow mapInput Data Penjualan Barang yang Diusulkan

Berdasarkan Gambar 4.4 berikut ini alur kerja sistem dalam transaksi penjualan yang akan di usulkan yaitu :

1. Konsumen memberikan data barang ke petugas

2. Petugas menginputkan data ke sistem untuk menghitung harga dan total harga yang kan di bayarkan

3. Jika konsumen menyetujui harga maka kunsumen melakukan pembayaran barang

4. Kemudian petugas membuat fakur

5. Petugas memproses data dan mencetak faktur

6. Faktur jual dan barang diberikan kepada konsumen

7. Dari hasil transaksi akan dijadikan sebagai laporan penjualan

8. Petugas kemudian melaporkan hasil transaksi penjualan kepada pemilik.

\subsection{Perancangan Sistem}

\subsubsection{Data Flow Diagram (DFD)}

Data flow diagram (DFD) disebut juga dengan diagram arus data $(D A D)$. DFD adalah suatu model logika data atau proses yang dibuat untuk menggambarkan darimana asal data dan kemana tujuan data yang keluar dari sistem, dimana data disimpan, proses apa yang menghasilkan data tersebut dan interaksi antara data yang tersimpan dan proses yang dikenakan pada data tersebut

\section{a. Diagram Konteks}

Berikut ini gambar Diagram konteks sebagai berikut :

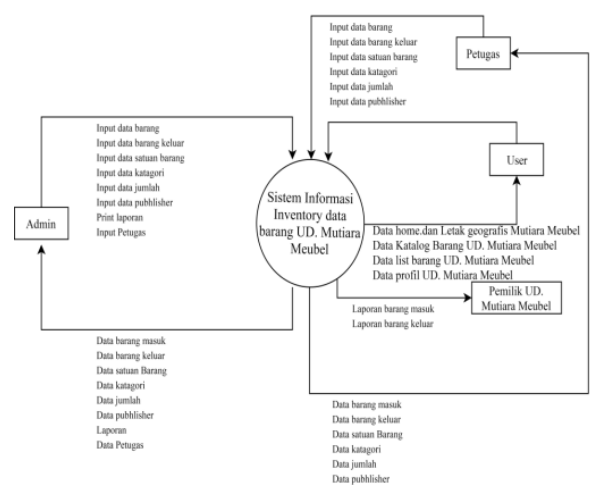

Gambar 4.5 Diagram Konteks

Diagram Konteks ini merupakan penggambaran secara garis besar Sistem Informasi inventory barang yang dibuat untuk mengetahui hubungan langsung antara user dengan sistem.

\section{b. Diagram Level 0}

Berikut ini gambar Data Flow

Diagramlevel 0 yaitu :

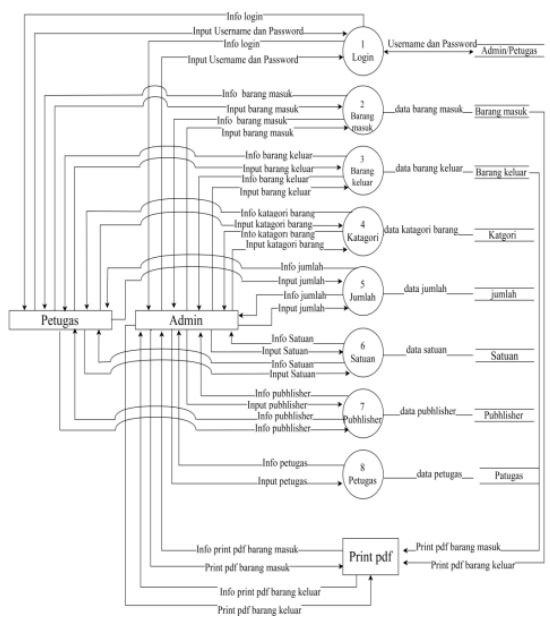

Gambar 4.6 Diagram Level 0

Pada gambar perancangan DFD level $O$ diatas dijelaskan 
secara umum dari sistem inforamasi inventory data barang UD.Mutiara Meubel Yang dimana pengguna atau user menginput data-data diantaranya data login, data barang masuk, data barang keluar, data data katagori, data jumlah, data satuan data pubhlisher dan petugas kemudian pada tabel daftar barang, daftar barang masuk dan daftar barang keluar admin atau penguna dapat melakukan print pdf.

\section{c. Diagram Level 2}

Berikut ini gambar Data Flow Diagramlevel 2 yaitu:

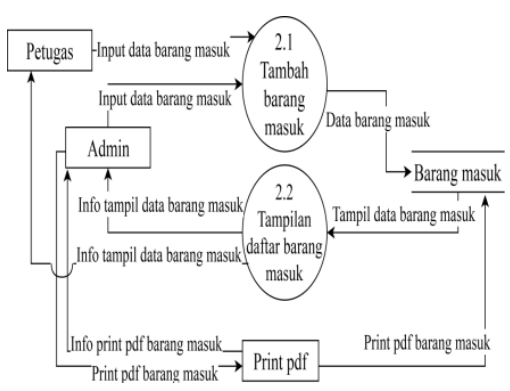

\section{Gambar 4.8 Diagram Level 2 Tambah Barang}

Pada tampilan gambar diagram merupakan penjabaran yang lebih detail tentang tambah barang masuk. Yang dimana penginputan bertujuan untuk mendata barang masuk dan dapat melakukan print pdf dengan cara mencetak laporan barang yang telah diinput.

\subsubsection{Entity Relationship Diagram (ERD)}

Entity Relationship Diagram digunankan untuk melihat hubungan antara entitas yang terdapat dalam Sistem Inventory Data Barang UD. Mutiara Meubel. Berikut adalah ERD yang terdapat dalam sistem pengelolaan data:

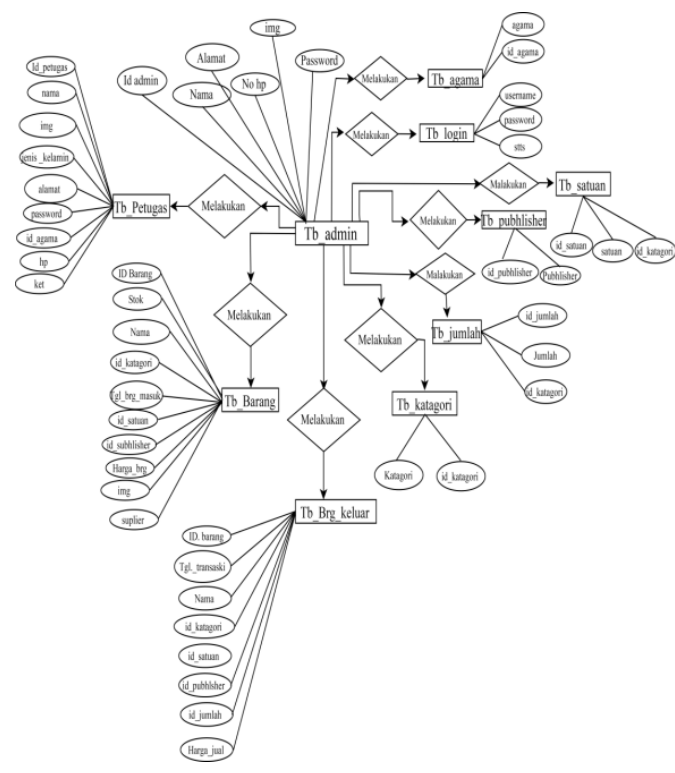

Gambar 4.7Entity Relationship Diagram

1. Rancangan tampilan tambah barang masuk admin merupakan tampilan form input pada UD. Mutiara Meubel.

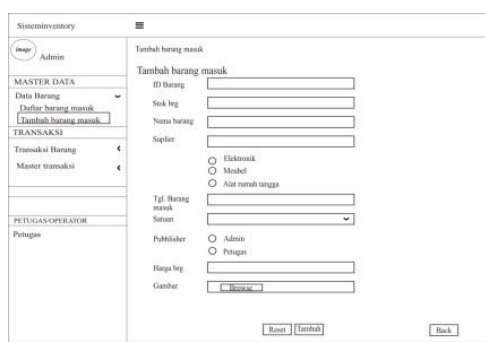

Gambar 4.8Tampilan Input Barang Masuk Admin

Rancangan

tampilan tambah barang ini merupakan tampilan form input tambah barang yang terdiri dari beberapa form seperti form id barang, stok barang, nama barang, dan pada tampilan ini terdapat juga cek box untuk memilih katagori barang pada form gambar terdapat button input untuk mengaploud file gambar dan buttonSubmit pada tombol tambah untuk menyimpan data yang telah input dan dapat melakukan reset pada buttonreset terdapat pula button back untuk dapat kembali ke halaman sebelumnya. 


\section{Flowchart menu Admin}

\section{a. Flowchart Tambah Barang Masuk Admin}

Adapun perancangan flowchart tambah masuk barang yaitu sebagai berikut:

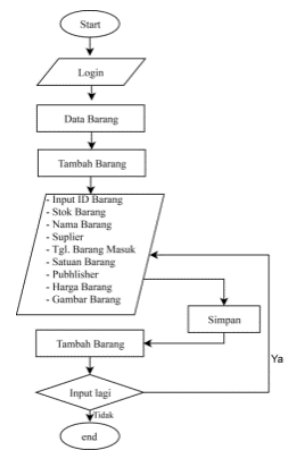

Gambar 4.9 Rancangan Flowchart Barang Masuk Admin

Pada flowchart tambah barang dijelaskan ketika penguna atau admin sudah dapat masuk .ke dalam sistem, maka akan tampil halaman menu utama admin dan terdapat button list data barang, dibawahnya terdapat button tambah barang yang berfungsi untuk menampilka halaman form tambah data barang, pada form tambah barang terdapat beberapa form input yang harus input diantaranya id barang, stok barang, nama barang, tanggal barang masuk, satuan barang, Pubhlisher, harga barang, gambar barang, dan keterangan barang. Setelah selsai diinput semua maka penguna atau admin dapat menyimpan dengan mengklik button simpan agar dapat tersimpan ke dalam databases barang.

\section{a. Halaman Daftar Barang Masuk} Menu Admin

Berikut adalah tampilan halaman daftar barang masuk Sistem Informasi Inventory Data Barang UD, Mutiara Meubel.

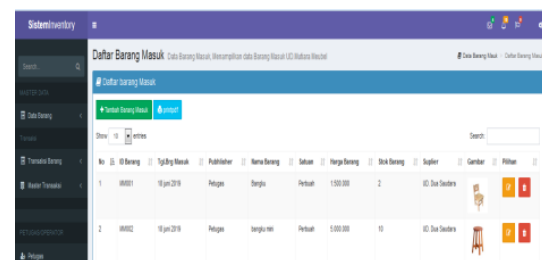

Gambar 4.10Tampilan Halaman Daftar Barang Masuk Admin

Halaman daftar barang masuk digunakan untuk menampilkan datadata barang masuk UD. Mutiara Meubel seperti id barang, tanggal barang masuk, pubhlisher, katagori barang, satuan, haraga barang, suplier, gambar dan pilihan.

b. Halaman Input Barang Masuk Menu Admin

Berikut adalah tampilan halaman input barang masuk Sistem Informasi Inventory Data Barang UD, Mutiara Meubel.

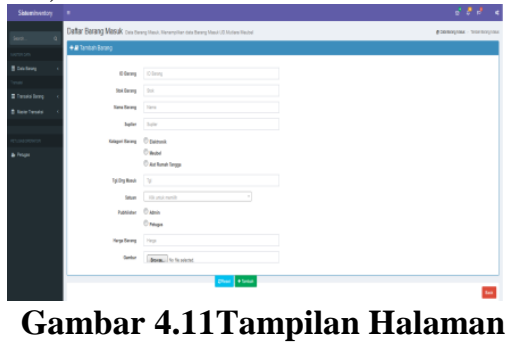

Tambah Barang Masuk Admin

Halaman tambah barang
masuk digunakan oleh petugas
(admin) untuk menambahkan data
barang masuk. Pada halaman ini
menampilkan beberapa form inputan
data barang seperti id barang,
tanggal barang masuk, pubhlisher,
katagori barang, satuan, haraga
barang, suplier dan gambar.

\subsubsection{Pengujian Login}

Pengujian yang dilakukan yaitu pengujian loginadmin seperti terlihat pada tabel dibawah ini : 
Tabel 4.1Pengujian Admin

\begin{tabular}{|l|l|l|l|}
\hline \multicolumn{4}{|c|}{ Kasus dan Hasil Uji (Data Benar) } \\
\hline $\begin{array}{l}\text { Data } \\
\text { Masukan }\end{array}$ & $\begin{array}{l}\text { Yang } \\
\text { Diharapk } \\
\text { an }\end{array}$ & $\begin{array}{l}\text { Pengam } \\
\text { atan }\end{array}$ & $\begin{array}{l}\text { Kesimpu } \\
\text { lan }\end{array}$ \\
\hline $\begin{array}{l}\text { Username: } \\
\text { admin } \\
\text { Password: } \\
\text { admin }\end{array}$ & $\begin{array}{l}\text { Muncul } \\
\text { menu } \\
\text { utama } \\
\text { sesuai hak } \\
\text { akses } \\
\text { Admin }\end{array}$ & $\begin{array}{l}\text { Muncul } \\
\text { menu } \\
\text { utama } \\
\text { admin }\end{array}$ & Diterima \\
\hline \multicolumn{2}{|c|}{ Kasus dan Hasil Uji Coba (Data Salah) } \\
\hline $\begin{array}{l}\text { Data } \\
\text { Masukan }\end{array}$ & $\begin{array}{l}\text { Yang } \\
\text { Diharapk } \\
\text { an }\end{array}$ & $\begin{array}{l}\text { Pengam } \\
\text { atan }\end{array}$ & $\begin{array}{l}\text { Kesimpu } \\
\text { lan }\end{array}$ \\
\hline $\begin{array}{l}\text { Data } \\
\text { kosong }\end{array}$ & $\begin{array}{l}\text { Kembali } \\
\text { ke } \\
\text { halaman } \\
\text { login }\end{array}$ & $\begin{array}{l}\text { Kembali } \\
\text { ke } \\
\text { halaman } \\
\text { login }\end{array}$ & Diterima \\
\hline Data salah & $\begin{array}{l}\text { Kembali } \\
\text { ke } \\
\text { halaman } \\
\text { login }\end{array}$ & $\begin{array}{l}\text { Kembali } \\
\text { ke } \\
\text { halaman } \\
\text { login }\end{array}$ & Diterima \\
\hline
\end{tabular}

\section{PENUTUP}

\subsection{Kesimpulan}

Kesimpulan yang bisa diambil dari skripsi ini yaitu Sistem Informasi Inventory data barang UD. Mutiara Meubel. Telah berhasil dibangun dengan menggunkan bahasa pemrograman PHP (Hypertext Preprocessor) dan database MySQL. Sistem yang dibangun merupakan sistem yang digunkan untuk mempermudah pengguna dalam melakukan pendataan barang masuk, barang keluar dan mempermudah dalam hal pencarian ketersedian barang, membuat laporan dari taransaksi barang masuk dan keluar serta mengenalkan produk-produk barang apa saja yang terdapat pada UD. Mutiara Meubel.

\subsection{Saran}

Berdasarkan kesimpulan yang telah di uraikan diatas, maka diperlukan adanya pengembangan pada Sistem Informasi inventory data barang yaitu tidak hanya dapat melakukan pendataan barang masuk, barang keluar dan mengenalkan produkproduk barang yang terdapat pada toko melaikan bisa adanya pengembangan lebih lanjut untuk merancang sistem agar menambahkan berbagai fitur menarik serta menambahkan proses pembelian barang yang sesuai dengan kebutuhan.

\section{DAFTAR PUSTAKA}

Arief, M. Rudianto. 2011. Pemrograman Web Dinamis menggunakan PHP dan MySQL. Yogyakarta: Andi Offset

A. S., Rosa dan Shalahuddin, M. 2013. Rekayasa Perangkat Lunak Terstruktur Dan Berorientasi Objek. Informatika. Bandung.

Afrianto, Irawan. 2011. "Modul Kuliah Sistem Multimedia. Jurusan Teknik

Informatika." Dalam Jurnal ilmia Unikom, Vol. 12, No.1

Basuki, A. T. dan Imamuddin Yuliadi. (2015). Ekonometrika Teori \& Aplikasi. Yogyakarta: Mitra Pustaka Nurani.

Buana, I Komang Setia. 2014. Jago Pemrograman PHP. Jakarta : Dunia Komputer.

Daqiqil, Ibnu. 2011. Framework CodeIgniter sebuah panduan dan best practice. Pekanbaru: CV Nasadana.

Hakim. 2010. Membangun Web Berbasis PHP dengan Framework CodeIgniter. Jakarta : PT Gramedia.

Ilham Madjid, Putra. (2011). “ Implementasi Sistem Informasi Manajemen Kepegawaian (SIMPEG) Pada Badan Kependudukan dan Keluarga Berencana Nasional”. Skripsi. Depok: Jurusan Ilmu Administrasi Negara Universitas Indonesia.

Komputer, Wahana. 2010. Panduan Belajar MySQL Database Server. Jakarta: Mediakita.

Nugrahayati Fatim. Perancangan sistem informasi inventory sparepart mesin. 2015.

Nugroho, Bunafit. 2013. Dasar Pemrograman Web PHP - MySQL dengan Dreamweaver. Yogyakarta: Gava Media.

Pressman R.S. 2015. Rekayasa Perangkat Lunak:: Pendekatan Peraktisi Buku I Yogyakarta: Andi 